\title{
The Disconnect between Old Age Social Security and Nigeria's Poverty Intervention Programmes
}

\author{
JKJ Okonkwo PhD, Cletus Iortyer Yissa
}

\begin{abstract}
This paper reviewed poverty intervention programmes in Nigeria with a view to pinpointing the disparity between the aged and other vulnerable demographics. The paper relied principally on secondary data elicited from previous poverty policies and programmes. The framework of analysis was the optimal redistribution model - a subset of the efficiency theory of social security propounded by James Mirrlees in 1971 - which recognizes public social security as a provision made specifically for the welfare of the elderly. The results of the analysis confirmed that poverty alleviation programmes (PAPs) have clearly demonstrated a generational inequity with increased and sustained prejudice against older people. Apart from the retirement benefit schemes which are statutory, the elderly suffered exclusion and have been conspicuously missing in poverty alleviation initiatives in the country. None of the programmes has specifically targeted them, hence, the group is delinked, disempowered and severely disabled, leading to extreme poverty as well as miserable and precarious living conditions. The paper advocated inclusivity of the aged through a special PAP designed to cater specifically for the group. Such a programme should establish old age care-centres where the aged could be guaranteed shelter, food, clothing, medical and healthcare, entertainment among other social needs.
\end{abstract}

Index Terms - Nigeria, Old-age, Poverty alleviation programmes, Social security.

\section{INTRODUCTION}

The sustained alienation of the aged in poverty policies and programmatic interventions in Nigeria has had far-reaching implications on the living conditions of this group of citizens. Available statistics shows that public poverty initiative and intervention programmes manifest a demographic bias against the elderly. Apart from the retirement benefit schemes which target retired public servants, other poverty alleviation policies or strategies were and still are tailored towards children (example Child's Care Trust [CCT], Poliomyelitis Eradication Initiative [PEI]) and the youth (example National Directorate of Employment [NDE], Youth Investment Fund [YIF]) or gender-oriented towards women (like the Better Life for Rural Women Programme [BLRWP], Women's Rights Advancement and Protection [WRAP]). Older people are, as [1] note, perceived as not 'deserving' but burdensome so issues concerning ageing attract minimal interest in developmental decisions. [2] affirms similarly that older people's poverty is not a priority in socioeconomic discourse of developing nations. [3] equally opines that although a significant proportion of the elderly in developing countries

JKJ Okonkwo, PhD, Department of Public Administration, Akanu Ibiam Federal Polytechnic, Unwana, Afikpo, Ebonyi State, Nigeria.

Cletus Iortyer Yissa, Department of Public Administration, Akanu Ibiam Federal Polytechnic, Unwana, Afikpo, Ebonyi State, Nigeria are substantially economically weak and incapacitated, older people still suffer exclusion from social protection programmes. Research has shown that Nigeria has neither a clear public policy nor functional social security system for the elderly $[4,5,6,7]$. Public-owned institutionalized centres (or homes) to cater for the housing needs of the elderly are also something of a rarity or completely non-existent.

Poverty, therefore, remains intractable, debilitating and exerts excruciating and devastating effects on the group due to weak capacity to generate income. The phenomenon has elicited concerns, reactions or comments among policy analysts, practitioners, media discussants, public commentators and scholars who view the trend as portending serious danger to old age security at present and in the future. From the perspective of gerontologists and gerontocratic interest groups who also reckon with the problem, the neglect is a deliberate and utter disregard of the contributions of these elderly citizens to nation-building during their working age, which tends to vitiate the intergenerational contract guaranteeing the upkeep, maintenance and welfare of the old, inactive and non-working adults through the redistribution or transfer of resources from the actively working age population.

As [8] and [6] observe, while there is vast literature on poverty, the specific focus on old age and old age well-being is scanty. This study contributes to boosting or expanding that literature. Again, majority of the studies on old age poverty particularly in Nigeria like that of Animasahun and Chapman [9] advocate special social policy enactments to cater for the needs of the group. However, none of the studies has specifically reviewed previous or existing poverty intervention programmes to provide evidence of the policy lacuna, neglect or exclusion of the old. This study equally fills that void. Efforts are made by the study to scan some of the PAPs implemented in Nigeria over the decades with the aim of exposing their prejudice against the older adults. The paper relied principally on secondary data culled from those policies and programmes, as well as evidence from literature on social security to arrive at results.

The paper is organized into five sections. Following this introductory which forms the first section, extant literature and theoretical underpinnings on the concept, dimensions (and rates of poverty in Nigeria over time), as well as the concepts of old age and social security are examined in the next section, which is section two. The third section presents and analyzes the data gathered by the study which comprise mainly poverty intervention strategies by successive administrations and wives of Nigerian military and political leaders. In section four, an attempt is made to expose and explain the exclusivity or disconnection of the aged from the various poverty initiatives over the decades. Conclusions are drawn and recommendations made in the final section. 


\section{LITERATURE REVIEW}

\section{A. Conceptualizing Old Age Social Security}

Conceptually, old age is a time in one's life when one is advanced in years of age above a particular threshold. The aged are regarded as people who are 60 years old or older [10]. In Nigeria, for example, one's old age is considered to set in at age 60 years when the individual's physical and mental abilities begin to diminish. Old age thus brings with it general weakness of parts of the body leading to reduced agility and capacity to move, work or actively perform daily life activities.

Globally, the population is ageing and the number and proportion of older people are increasing across countries. The [11] states that people aged 60 years and over constitute 12.3 percent of the global population, and this trend is likely to rise to about 22 percent by year 2050 . The age distribution in many countries is shifting towards an older population due to low fertility and improved nutrition which have culminated in increasing longevity (Kholi, as cited in [1]). Other factors precipitating the rise in the number of older persons, as [6] outline, include among others decreasing mortality rate, pervasive and endemic poverty, as well as socioeconomic hardship. The shift is higher and faster in the developing counties where already two-third of the world's older people is living [12]. This means that there is a substantial increase in the number of older people in the population of countries [13] which is why the [11] projected that the number of people aged 60 years or more may hit 2 billion or over by 2050.

Nigeria's population is estimated at 200 million with a growth rate of the other demographics at 2.6 percent while that of the elderly aged 65 years and over is 3.2 percent or 5.9 million in absolute numbers $[14,15,16]$, which is projected to double by 2050 [17]. The implication of this demographic trend is that Social Security (SS) arrangements are not only imperative but should be comprehensive and inclusive of the elderly in order to reduce old age poverty and guarantee the well-being of the older adults.

Old age SS is the provision made by a society for older individuals to guarantee them good living conditions and prevent old age poverty and deprivation. It is a special protection for the elderly by the state, market, or civil society to enable them to access income and other basic necessities to reduce multi-dimensional deprivation. [18] states that old age SS represents a range or set of benefits or programmes provided by the state which are aimed at protecting older citizens against poverty and other deprivations commonly associated with the group. Pension benefits, social insurance, old age homes, healthcare and adult education are among some of the old age security programmes often adopted by most countries to cater for and improve the well-being of older citizens. For example, the Abia State Government inaugurated the Free Home Access Programme for older persons in 2017 [19]. In developing countries including Nigeria, some of the dimensions of SS are deliberately morphed together as PAPs aimed at ameliorating the poverty suffered by vulnerable groups (Cohen, as cited in [20]). In the developed world, older people are the target of SS programmes or PAPs and were indeed the first beneficiaries of the welfare state [21]. Strong SS systems along with other poverty reduction measures combine to raise the living standards of older people in wealthy nations [13]. In New Zealand, for instance, [1] point out that living standards are highest among the elderly because the state takes care of older people more than the young. In Europe, retired older people have greater and easy access to effective, well-functioning and reliable social pension schemes as a dependable source of income [3].

\section{The Poverty Discourse}

The multi-dimensional, pervasive and complex nature of poverty which affords it varying definitions is a well-acknowledged fact. The various definitions though address different aspects of the phenomenon eventually crystallize to a common denominator which is income. In other words, poverty as lack of income is the dominant perception by nearly all the definitions and entails that individuals or families do not possess sufficient financial resources that will afford them the basic needs of life such as food, clothing and shelter. The [22] describes poverty as not having enough money to access food, clothes, education, medical care or services which demean the capacity of the affected person to participate effectively in societal activities. Nigeria's Development Prospects (as cited in [23]), defines poverty in a similar perspective as lack of income which limits individual ability and capability, denying them access to material possession in addition to choices and opportunities thereby leading to human degradation and low (or sometimes zero) self-esteem.

Poverty may be absolute in which case the victims are unable to access the basic necessities of food, clothing, shelter, decent or serene environment and sanitation, safe water and so forth. It may also be relative when citizens do not have the capacity to access credit facilities or funds. Individuals find themselves in such conditions or circumstances due to lack of employable skills, gainful employment or reasonable education. As a result, they are unable to meet social and economic obligations and so live in precarious areas with deplorable conditions that are below the base line threshold for measuring poverty. [24] argues that income poverty exerts monumental socioeconomic and physical effects on individuals. It manifests or occurs in two levels: primary poverty which arises from insufficient individual or family finance to satisfy the daily needs of life and, secondary poverty which is a product of mismanagement of economic resources by an individual or a family [25]. Poverty perceived as lack of access to basic amenities is a condition in which individuals, families and groups do not enjoy minimum standards of living due to inaccessibility to basic social and economic infrastructure such as medical and health services, safe water and sanitation, education, transport and communication facilities. This is referred to by [26] and [23] as infrastructure poverty. Poverty may also be classified as physiological and psychological. Physiological poverty is associated with absolute and primary poverty while psychological poverty is linked with mentality or regarded as mental poverty popularly referred to as poverty of the mind, 
indicating lack of ideas, or low self-esteem (and sometimes greed) which leaves individuals who may be rich materially or physiologically but still behave as though they were poor.

A holistic conceptualization of poverty morphs all the perspectives into a unified phenomenon whose basic manifestation is weak per capita income that culminates in poor access to basic necessities, a condition which incapacitates individuals, denying them ordinary well-being as well as excluding or preventing them from participating in meaningful societal activities [27]. [28 and 29] describe the condition as creating deprivation and vulnerability, disillusionment and humiliation, as well as social inferiority and isolation while Robert McNamara refers to it as a life-degrading condition that insults human dignity [30].

\section{D.Incidence of Poverty in Nigeria}

Nigeria is overwhelmingly poverty-stricken. The country is ranked among the top five countries harbouring the largest number of poor people (World Bank, as cited in [31]). The UN Common Country Analysis (CCA) described Nigeria as one of the poorest countries in the world while data from the [32] ranked Nigeria among the 40 poorest nations in the world [33]. The National Bureau of Statistics (NBS) reported in 2013 that over 112 million Nigerians representing more than 67 percent of the country's population lived below the poverty line [34]. The World Bank's 2019 Economic Update Report on Nigeria indicates that about 50 percent of the country's estimated 200 million people live in extreme poverty, with an estimated 100 million living on less than US $\$ 1.90$ per day [35]. In the same report, the Brookings Institution pointed out that data from the World Poverty Clock showed that 87 million people in Nigeria are living in poverty. Sadly, the report noted that Nigeria overtook India in 2018 as the country with the largest number of people living in extreme poverty implying that the country is probably now number one in the world. The bank further projected in the report that extreme poverty may rise to 25 percent (equivalent of 30 million people in crude numbers) by year 2030. The 2019 NBS report on poverty and inequality in Nigeria based on data from the Nigeria Living Standards Survey (NLSS) conducted between September 2018 and October 2019 depicts a similar trend or scenario. The report indicates that 40 percent representing about 83 million people of Nigeria's total population live below the country's poverty line of NGN137,430 (US\$381.75) per annum [14].

These figures no doubt reveal the reality that poverty rates in Nigeria have persistently and exponentially remained high over the years - 66 percent in 1996 and 70 percent in 2000 [31], 54.7 percent in 2004 [36], 60.9 percent in 2010 [37], 61 percent in 2012 [38] and 64 percent in 2016 [33]. Poverty prevalence diminished to 39.1 percent in 2018 and rose slightly to 40 percent in 2019 [39]. [40] notes that poverty incidence has been on the rise both within and among locations in Nigeria. The severity and intensity of the menace is higher on the country's vulnerable demographics children, women and the elderly which is perhaps why the International Monetary Fund (IMF), World Bank and the
Nigerian Economic Summit Group in 2020 called on the government to frontally tackle the poverty situation in the country in order to sustain her economic gains [41].

\section{E. Poverty Alleviation}

Poverty alleviation simply denotes making poverty less severe among the population. This is done through policy and institutional frameworks that build capacity to improve skills and create wealth which boosts individual and family income. Its correlate, poverty reduction on the other hand means causing poverty to diminish in spread across the country. Both concepts are used interchangeably in this paper.

Poverty alleviation programmes are conscious and deliberate measures put in place to reduce the severity and spread of poverty among the population. They represent mechanisms initiated by the public, private or voluntary sector to remedy adversity and deficiencies of the vulnerable or potentially vulnerable groups in the society. At the governmental level, PAPs refer to packages put together by the government intended to empower or provide assistance to the needy or least favoured groups in the society in order to guarantee them access to resources like income that would enable the acquisition of basic needs such as food, shelter, healthcare among others, which will uplift their fortunes and significantly improve their socioeconomic well-being. They are SS strategies designed to promote the well-being of the population at large, but often target demographic groups like children, women, the elderly, unemployed, sick, physically challenged who are most susceptible to the vagaries and travails of the economy. PAPs may be broad-based or sector-specific and include free healthcare and education, unemployment allowances, pension schemes, disability and sick benefits among others. [3] laments that sub-Saharan African (SSA) countries lack effective and functional social protection systems to mitigate the poverty of older people.

\section{ANALYTICAL FRAMEWORK}

The framework of analysis that underpins discussions in this paper is the optimal redistribution model - a variant of the efficiency theory of SS propounded by James Mirrlees in 1971. The theory views SS programmes as basically welfare for the elderly. It holds that inefficiencies, imbalances or excesses inherent in the market mechanism prevent it from alleviating the poverty of older people so the government steps in by creating SS programmes (Cohen, as cited in [20; 42]). [43] observes that the post World War II events gave rise to the social-democratic state (also known as the welfare state) with enormous economic and social responsibilities for its citizens, discharged through a range of SS or poverty alleviation mechanisms. Chancellor Otto Von Bismarch who entrenched some of the welfare strategies like pension benefits remarked that whoever has a pension to lean on at old age is much more contented and more easily catered for than one who has no prospect of any. He stressed that such pension will make the ordinary citizen regard the Empire as a benevolent institution (Ritter, as cited in [42]). 
Optimal redistribution implies that government's intervention in social welfare through SS or PAPs is to ensure fair and just distribution of wealth between the rest of the population and the older citizens. This is predicated on the intergenerational contract in which citizens contribute to nation-building during their productive years, and receive support from the state when they cease to work [1]. Part of the revenue raised from the productive labour force is used to maintain and sustain the elderly who have weak capacity for generating income. A significant proportion of public expenditure is made on old age social protection - pension and allowances, medical and healthcare, old age homes and so forth - which the market is reluctant or fails to provide due to preoccupation or concern with market efficiency and profitability to the neglect of social welfare services. With this, optimal redistribution is believed to produce results that are socially balanced and acceptable in the society because "the old receive greater weight and attention in public decisions [20].

Poverty intervention programmes in Nigeria exhibit a radical departure from Mirrlees' model, contrast sharply to the position in the developed world and completely negate parts of Section 16 (2) (d) of the 1999 Constitution of the Federal Republic of Nigeria (as amended) which promises to provide suitable and adequate shelter, as well as old age care and pensions. Clear preferences are shown to the other demographics particularly children, women and youths vis-à-vis the aged. The PAPs demonstrate selective deprivation and inequalities against the older adults. In fact, the aged are disconnected from most of the PAPs as none specifically caters for their welfare or takes care of their needs. As [4] observe, there is clear prejudice or discrimination against the elderly and this has worsened the poverty situation of the group. Even the pension arrangements that target the retired public workers are weak, mal-functional or improperly managed and therefore least successful and unsustainable, characterized by irregular

Table 1: Multi-sector public-initiated PAPs

\begin{tabular}{|c|c|c|c|}
\hline Prgramme & Year & Main Objective & Targeted beneficiaries \\
\hline $3 \mathrm{Rs}$ & 1970 & $\begin{array}{cc}\text { Post-civil } & \text { war } \\
\text { empowerment. }\end{array}$ & $\begin{array}{l}\text { Citizens of the } \\
\text { south-east region }\end{array}$ \\
\hline NDE & 1989 & Employment generation & The youth \\
\hline NERFund & 1990 & Loans to SMEs & Poor citizens \\
\hline DFRRI & 1986 & Rural infrastructure & Rural dwellers \\
\hline OMPADEC & 1992 & $\begin{array}{c}\text { Empowerment and } \\
\text { development }\end{array}$ & Niger Deltans \\
\hline PTF & 1994 & Infrastructure provision & All citizens \\
\hline $\begin{array}{l}\text { Niger Delta } \\
\text { Development Commission } \\
\text { (NDDC) }\end{array}$ & 2000 & $\begin{array}{l}\text { Infrastructure and } \\
\text { development }\end{array}$ & Niger Deltans \\
\hline PAP & 2000 & Menial job employment & The youth \\
\hline PTDF & 2000 & $\begin{array}{l}\text { Improve technology in } \\
\text { oil and gas }\end{array}$ & The youth \\
\hline NAPEP & 2001 & Poverty alleviation & Poor citizens \\
\hline NDDC-SACP & 2004 & Youth skill training & Niger Delta youths \\
\hline NEEDS & 2004 & $\begin{array}{c}\text { Empowerment } \\
\text { poverty alleviation }\end{array}$ & $\begin{array}{c}\text { All citizens } \\
\text { emphasis on youths }\end{array}$ \\
\hline
\end{tabular}

payments or several months of non-payment across the levels of government while pensioners spend vain days and nights at banks and other designated centres in the name of screening or verification. This further increases the social isolation and sometimes abandonment often suffered by the elderly, leading to deteriorating poverty conditions among the group.

\section{PUBLIC INTERVENTION IN POVERTY ALLEVIATION IN NIGERIA}

The quest to reduce or eradicate poverty in Nigeria dates back to the period immediately after independence. Landmark attempts actually began with the post-civil war poverty arrangement referred to as the $3 \mathrm{Rs}$ - reconstruction, rehabilitation and reconciliation - an initiative of the then Head of State, General Yakubu Gowon, aimed at rebuilding the South-east region which was destroyed by the civil war. This did not yield the desired results though. However, more organized and coordinated efforts were made during the era of National Development Planning (1970s and 1980s). Having realized that proceeds of the oil boom were recklessly mismanaged thereby intensifying the poverty syndrome, it became pertinent to revert to agriculture hence most of the poverty reduction programmes were agriculture-based, targeted at boosting capacity production of the agricultural sector to ensure self-sufficiency in food and agro-allied raw materials. To achieve this, programmes such as Operation Feed the Nation (OFN) and the Green Revolution were put in place in the 1970s and 1980s respectively while agencies and institutions like the River Basin Development Authorities (RBDAs), Agricultural Development Programmes (ADPs), the Strategic Grain Reserve Programmes (SGRPs) among others were created to steer or foster back-ups. The programmes can be categorized into multi-sector and sector-specific PAPs shown in Tables 1 and 2. 


\begin{tabular}{|c|c|c|c|}
\hline $\begin{array}{c}\text { Subsidy Re-investment } \\
\text { Programme (SURE-P) }\end{array}$ & 2012 & $\begin{array}{c}\text { Alleviate subsidy } \\
\text { removal hardship }\end{array}$ & $\begin{array}{c}\text { All citizens but } \\
\text { emphasis on youths }\end{array}$ \\
\hline $\begin{array}{c}\text { National Social } \\
\text { Investment Programme } \\
\text { (NSIP) }\end{array}$ & 2016 & $\begin{array}{c}\text { Empowerment and } \\
\text { poverty alleviation }\end{array}$ & All citizens \\
\hline $\begin{array}{c}\text { North-East } \\
\text { Development Commission } \\
\text { (NEDC) }\end{array}$ & 2016 & $\begin{array}{c}\text { Reconstruction of the } \\
\text { north-east region }\end{array}$ & $\begin{array}{c}\text { Citizens of the } \\
\text { north-east region }\end{array}$ \\
\hline $\begin{array}{l}\text { Youth Investment Fund } \\
\text { (YIF) }\end{array}$ & 2020 & Youth empowerment & The youth \\
\hline SME Survival Fund & 2020 & $\begin{array}{l}\text { Post-COVID-19 SME } \\
\text { empowerment }\end{array}$ & SME owners \\
\hline $\begin{array}{c}\text { Anchor Borrowers } \\
\text { Programme (ABP) }\end{array}$ & 2015 & $\begin{array}{c}\text { Food sufficiency and } \\
\text { poverty alleviation }\end{array}$ & Farmers and youths \\
\hline INFRACO & 2020 & \multicolumn{1}{|l|}{ Infrastructure provision } & All citizens \\
\hline NPRGS & 2021 & Poverty reduction & All citizens \\
\hline
\end{tabular}

Source: Compiled by the authors (2021).

Interpretation:

NERFUND - National Economic Reconstruction Fund

OMPADEC - Oil Mineral Producing Areas Development Commission

PTF - Petroleum (Special) Trust Fund

PTDF - Petroleum Technology Development Fund

NAPEP - National Poverty Eradication Programme

NDDC-SACP - Niger Delta Development Commission's Skill Acquisition Programme

NEEDS - National Economic Empowerment and Development Strategy

INFRACO - Infrastructure Company

NPRGS - National Poverty Reduction with Growth Strategy

MSMEs - Micro, Small and Medium Enterprises

SMEs - Small and Medium Enterprises

The data in Table 1 reflect some of the poverty intervention initiatives of the federal government spanning a 5-decade period, beginning from the 1970s to the 2020s. The data reveal that while programmes such as DFRRI, PTF, NAPEP, NEEDS, SURE-P, NSIP, INFRACO, NPRGS had a national outlook - cutting across all states and geo-political regions - others like the 3Rs, OMPADEC, NDDC, NDDC-SACP and NEDC were region-specific, that is, restricted to geo-political zones due to regional peculiarities regarding environmental degradation, security and abject poverty. It is also discernible that some of the PAPs were meant to address absolute poverty, example, OFN, ADPs, Green Revolution, SGRP while others such as PTF, NDDC, NEEDS, NDE, SURE-P, NSIP were devolved to tackle both absolute and relative poverty. Most significantly, it is evident from the data that majority of the initiatives though claim to embrace all citizens, specific groups preferably youths and women often benefit, with little or absolutely no attention to the elderly. For example, the youth enjoy exclusive attention in NDE, PAP, PTDF, NDDC-SACP and YIF while the older citizens do not have a stake or share in any of the progammes.

Table 2: Sector-specific government intervention PAPs

\section{Sector}

Agriculture
Programme/Policy

National Accelerated Food Production

Programme (NAFPP)

OFN

RBDAs

ADPs

Agricultural Credit Guarantee Scheme

(ACGS)

Green Revolution

Nigerian Agricultural Insurance

Corporation (NAIC)

SGRP

National

Development Authority (NALDA)

Nigerian Agricultural Cooperative and

Rural Development Bank (NACRDB)

Bank of Agriculture
Year

1974

1976

1976

1976

1977

1979

1988

1989

Land 1991 


\begin{tabular}{|c|c|c|}
\hline & Anchor Borrowers Programme (ABP) & 2015 \\
\hline & Green Alternative & 2016 \\
\hline \multirow[t]{5}{*}{ Education } & Universal Primary Education (UPE) & 1977 \\
\hline & Nomadic Education Programme & 1989 \\
\hline & Adult and Non-formal Education & 1990 \\
\hline & Programme & \\
\hline & Universal Basic Education & 1999 \\
\hline \multirow[t]{16}{*}{ Health } & Poliomyelitis Eradication Initiative & 1988 \\
\hline & $\begin{array}{l}\text { Guinea Worm Eradication Programme } \\
\text { (GWEP) }\end{array}$ & 1988 \\
\hline & $\begin{array}{l}\text { National Programme on Immunization } \\
\text { (NPI) }\end{array}$ & 1997 \\
\hline & Expanded $\quad$ Programme & 1997 \\
\hline & Immunization (EPI) & \\
\hline & National Primary Health Care Delivery & 1992 \\
\hline & Agency (NPHCDA) & \\
\hline & $\begin{array}{l}\text { National Health Insurance Scheme } \\
\text { (NHIS) }\end{array}$ & 1999 \\
\hline & $\begin{array}{l}\text { National Malaria Control Programme } \\
\text { (NMCP) }\end{array}$ & 2001 \\
\hline & $\begin{array}{l}\text { National Centre for Disease Control } \\
\text { (NCDC) }\end{array}$ & 2011 \\
\hline & $\begin{array}{l}\text { The State House Health Investment } \\
\text { Programme (SHHIP) }\end{array}$ & 2011 \\
\hline & National Health Care Act & 2014 \\
\hline & National Primary Health Care & 2017 \\
\hline & Revitalization Programme (NPHCRP) & \\
\hline & Community Health Influenza, & 2018 \\
\hline & Promoters and Services (CHIPS) & \\
\hline \multirow[t]{4}{*}{ Finance } & People's Bank of Nigeria (PBN) & 1989 \\
\hline & Community Banks & 1995 \\
\hline & Microfinance Banks (MFBs) & 2007 \\
\hline & Development Bank of Nigeria (DBN) & 2016 \\
\hline Transportation & $\begin{array}{l}\text { Federal Urban Mass Transit Agency } \\
\text { (FUMTA) }\end{array}$ & 1988 \\
\hline \multirow[t]{6}{*}{ Industry } & Industrial Training Fund (ITF) & 1971 \\
\hline & Bank of Industry (BOI) & 2000 \\
\hline & $\begin{array}{l}\text { Small and Medium Industries Equity } \\
\text { Investment Scheme (SMIEIS) }\end{array}$ & 2001 \\
\hline & Small and Medium Enterprises & 2003 \\
\hline & $\begin{array}{l}\text { Development Agency of Nigeria } \\
\text { (SMEDAN) }\end{array}$ & \\
\hline & $\begin{array}{l}\text { Artisanal and Small-scale Miners Fund } \\
\text { (ASSMF) }\end{array}$ & 2018 \\
\hline
\end{tabular}

Source: Compiled by the authors (2021).

The data presented in Table 2 show the various sector-focused poverty intervention programmes evolved by successive administrations at the federal level to tackle the different dimensions of poverty using sectors of the economy. It is clear from the table that agriculture and health enjoy the highest level of attention, with the duo attracting a total of 24 policy initiatives ( 12 for either) equivalent to 64.84 percent of the overall interventions, signifying the importance attached to food sufficiency and security as well as health as citizens basic and fundamental needs. Industry received five policies representing 13.51 percent of the total while education and finance separately obtained four policies and programmes each amounting to 10.81 percent respectively or 21.62 percent taken together during this period. Some of the interventions like the People's Bank (later Community Bank), DBN aimed at combating relative poverty while others such as BOI, SMIEIS, SMEDAN and ASSMF targeted MSMEs for loans at convenient interest rates in order to boost or promote small-scale businesses. 


\section{EVIDENCE OF VOLUNTARY SECTOR INTERVENTION IN POVERTY IN NIGERIA}

The participation of the voluntary sector (also referred to as Non-Governmental Organizations [NGOs]) in poverty alleviation in Nigeria is relatively a recent phenomenon. It started in the mid-1980s, specifically during the military regime of General Ibrahim Babangida (rtd.), whose wife late Maryam, founded the BLRWP in 1987 as a fallout of the World Conference on Women Empowerment held in Beijing,
China the previous year. The programme opened the door for wives of successive heads of government at both federal and state levels to initiate PAPs (known as Pet Projects) of one kind or the other to reduce or possibly eradicate poverty among the less privileged groups. Most of the programmes were gender or group-specific while a few cut across sectors or groups. Tables 3 and 4 summarize the cross-gender or cross-group and group-specific or gender-based non-governmental PAPs initiated by successive First Ladies in Nigeria.

Table 3: Cross-gender or cross-group PAPs initiated by Nigerian First Ladies

$\begin{array}{lll}\text { Programme } & \text { Initiator } & \text { Year } \\ \text { Family Support Programme (FSP) } & \text { Maryam Abacha } & 1994 \\ \text { FEAP } & \text { Maryam Abacha } & 1997 \\ \text { Future Assured Programme (FAP) } & \text { Aisha Buhari } & 2015 \\ \text { Source: Compiled by the authors (2021) } & \end{array}$

Source: Compiled by the authors (2021).

Table 4: Gender or group-specific PAPs initiated by Nigerian First Ladies

\begin{tabular}{|c|c|c|c|}
\hline Programme & Initiator & Year & Targeted Group \\
\hline BLRWP & Maryam Babangida & 1987 & Women \\
\hline WRAP & Fati Lami Abubakar & 1998 & Women \\
\hline $\mathrm{CCT}$ & Stella Obasanjo & 2000 & Children \\
\hline WAYEF & Turai Yar'Adua & 2007 & Women and youths \\
\hline Affirmative Action (AA) & Dame Patience Jonathan & 2011 & Women \\
\hline
\end{tabular}

Interpretation:

FEAP - Family Economic Advancement Programme

WAYEF - $\quad$ Women and

Youth Empowerment Foundation sector-specific PAPs in critical sectors of health, food security, finance and education targeted the elderly minimally and with half-hearted attention. In the education sector, for example, only the adult and non-formal education programme and probably the UBE programme were of benefit to the aged. The focus groups in the adult and non-formal education programme were mostly early school leavers, prison inmates, out-of-school boys, adolescent girls, and Quranic school children. In the health sector, the GWEP and NMCP made marginal impact on old age healthcare. Both the National Healthcare Act and the National Primary Healthcare Delivery Policy have no special provision for the elderly. In the same vein, both the routine and supplemental immunization service delivery of the NPI and EPI targeted mostly women and children but not the older adult citizens. Worse still, the NHIS serves only public servants in active service; retirees cannot and do not access the scheme. The NSIP of the Buhari administration has several components the Home Grown School Feeding of children, the N-Power Programme, Conditional Cash Transfer and Government Enterprise and Empowerment Programme (GEEP) but none has been exclusively dedicated to the aged. All except the Conditional Cash Transfer are designed in favour of the youth, women and children.

A careful examination of both the public and voluntary PAPs in Tables 1-4 reveals a clear bias against the aged in Nigeria. Public poverty intervention programmes whether cross-sector or sector-specific have paid little or no attention to the elderly. For example, multi-sector poverty initiatives such as NAPEP, PTF, NEEDS and so forth never incorporated older people as a special target. Similarly,

The story is not different in the voluntary sector intervention PAPs. The multi-sector PAPs initiated by wives of Nigerian leaders rarely carved a space for older people. For example, FSP and FEAP had no special place or consideration for the elderly. The Future Assured initiative sponsored by Aisha Buhari focuses more on children, youth 
and women. The programme reluctantly included the aged in its free medical outreach for children and women launched in Jigawa State on November 30, 2017 [44].

It is understandable though that children, youth and women together constitute the largest population of about 72 percent or over of Nigeria's total population [23] and with the hardship occasioned by worsening economic and unemployment situations in the country, focus of PAPs on these groups is no doubt ethical. However, total excision of the elderly from poverty alleviation initiatives or interventions is worrisome because, as [45] notes, older people are economically inactive and therefore susceptible to income poverty and the other dimensions of well-

being. Even in the developed countries where older people enjoy effective social security protection systems, poverty is still (and usually) higher and intense among the group [46]. Moreover, it is argued that most of the older citizens contributed positively to nation-building during their working years so deserve due care and attention at old age in line with the prescriptions of the intergenerational contract on the one hand and the social contract entered into with all citizens by the Nigerian government on the other.

Further insights into the PAPs reveal that most of the policies and programmes failed because they suffered from what could be regarded as the paradox of policy in Nigeria characterized by beautifully formulated but poorly implemented policies. This failure is attributed in part to the top-down approach where nearly all the policies were initiated from Lagos (before 1991) and now Abuja, what [47] refer to as externally imposed or class mediated policies. In order words, the PAPs did not address the poverty concerns of the targeted groups because they were state-centric instead of people-centred, which thrive more on local initiative. There were also issues of poor or ineffective coordination of PAP activities among the lower tiers of government and the upper or national level [31] as well as corruption and beneficiary selection pressures from top bureaucrats and politicians. For example, the projects in Tables 3 and 4 were and usually are of personal interest to the First Ladies and embarked upon to change the poverty conditions of the vulnerable or under privileged groups. The conception, design and implementation of the programme or project are, therefore, the exclusive preserve of the First Lady concerned, who defines the mission and decides the target or beneficiary group(s). This explains why the project ceases or is discontinued as soon as the spouse leaves office. There are also concerns about the mode of funding and accountability, as well as personalization of the project at the expiration of the husband's term of office.

\section{CONCLUSION/RECOMMENDATIONS}

The intergenerational contract in which resources are taken from the active working population and committed to old age welfare and social security has not received adequate attention in Nigeria. Poverty intervention policies and programmes in the country whether public or voluntary have manifested bias against the elderly over the decades. Most of the programmes are group-focused, favouring mainly children, women and youths. The senior citizens have been conspicuously excluded, sidelined or least captured in PAPs so far implemented in the country. The socioeconomic conditions of this group are almost non-existent: old age homes and centres are scanty across the country so older people live in precarious houses, usually alone or sometimes sharing rooms with children particularly in the rural areas; access to food and basic services such as water, sanitation and electricity which are essential to ensure minimum living standards is limited. Deprivation is also rife in the critical sectors of health and entertainment as exemplified by high rates of illnesses and deteriorating health among the aged. The few state-funded SS services like pension and gratuities essential to keep old age poverty low are defective and not receiving the desired commitment, attention or support. This has resulted to all forms of basic and essential deprivations, making access to sustenance difficult thereby exacerbating old age poverty. There is, therefore, urgent need for a special PAP to be designed and devoted to catering for the old. The policy or programme should endeavour to establish at least one old age care centre or home in each state of the federation where older citizens could access food, shelter, medical care and entertainment. Such centres will also make the aged easily accessible by charitable individuals and organizations. This will reduce the severity of poverty and increase longevity among the group. The National Health Insurance Scheme for All Nigerians (NHISAN) Bill undergoing consideration in the National Assembly is an important milestone because the elderly are expected to benefit from the Scheme when the bill becomes law. It is expectantly pertinent and significant that the NPRGS - a 10-year poverty reduction plan - formulated by the Buhari administration (Table 1) prominently ensures access and inclusivity by creating a special unit that would adequately cater for the welfare of the elderly.

\section{REFERENCES}

[1] K. Turley, M. Breheny and K. Tuffin, Intergenerational inequity arguments and the implications for state-funded financial support of older people. Ageing and Society, 37, Cambridge: Cambridge University Press, 2015, pp. 561-580.

[2] H. Epstein, (2001, April 12). Time and indifference (pp.33-38). New York Review of Books.

[3] O. Adisa, Why are some older persons economically vulnerable and others not? The role of socio-demographic factors and economic resources in the Nigerian context, 2019.Ageing International (2019) 44: 202-222. Available: https://dio.org/10.1007/s.12126-01909348-8.

[4] P.L. Tanyi, P. Andre' and P.O. Mbah, Care of the elderly in Nigeria: Implications for policy. Cogent Social Sciences, 4(1), 1555201, 2018. Available: dio:10.1080/23311886.1555201.

[5] S.O. Ebimgbo, S.O.; Atumah, O.N. \& Okoye, U.O. (2017). Social support, older adults poverty: Implication for social policy inNigeria.Available:https://www.researchgate.net/publication/319109 491.

[6] S.A. Adebowale, O. Atte and O. Ayeni (2012). Elderly well-being in a rural community in North Central Nigeria, sub-Saharan Africa. Scientific and Academic Publishing , 2012, 2(4): 92-101. Available: dio:10.5923/j.phr.20120204105.

[7] B.R. Fajemilehin and A.I. Odebiyi, Predictors of elder persons' quality of life and health practices in Nigeria. International Journal of Sociology and Anthropology, 2011, 3(7): 245-252. Available: https://www.academicjournals.org/USA. 
[8] C. Kwan and C.A. Walsh, (2018). Old age poverty: A scoping review of the literature. Cogent Social Science, 2018 4: 1. Available: https://dio.org/10.1080/23311886.2018.1478479.

[9] V.J. Animasahun and H.J. Chapman, Psychological health challenges of the elderly in Nigeria: A narrative review. African HealthSciences, 2017,17(2):575-583.Available: dio.10.4314/ahs.v.17i2.35.

[10] Help Age International, State of the world's older people, 2002. London: Help Age International, 2002.

[11] UNDESA - Population Division (United Nations Department of Economic and Social Affairs - Population Division), 2015, World population prospects: The 2015 revision. Available: https://www.un.org/en/developmen/desa/publications/wold-population -prospects- 15-revision.

[12] UNDESA - Population Division (United Nations Department of Economic and Social Affairs - Population Division), 2002, World population prospects: The 2002 revision. Available: https://www.un.org/en/development/desa/publications/world-populati on-prospects-15-revision.

[13] L. Gasparini, J. Alejo,F. Haimovich, S. Olvieri, and L. Tornarolli, Poverty among older people in Latin America and the Caribbean. Journal of International Development,2009, 22: 176-207.

[14] LSMS (Living Standards Measurement Survey) (2020, May 28). Nigeria releases new report on poverty and inequality in country. World Bank's Poverty Global Practice. Available: www.worldbank.org.

[15] PRB (Population Reference Bureau), World population data sheet, 2017. Washington DC, 2017.

[16] PRB (Population Reference Bureau,) (2012). World population data sheet, 2012. Washington DC, 2012.

[17] P.O. Mbah, The neoliberal state and administrative reforms in Nigeria. Afro-Asian Journal of Social Science, 2016, VII (III): 1-30.

[18] A. Barrientos, Latin America: A liberal informal welfare regime. In: L. Gough, G. Wood, A. Barrientos, P. Bevan, P. David and G. Room (eds.), Insecurity and welfare regimes in Asia, Africa and Latin America. Cambridge: Cambridge University Press, 2004, PP. 356-410.

[19] Radio Nigeria (2017, December 1). 7pm Network News Panorama.

[20] C.B. Mulligan and X. Sala-i-Martin, Social security in theory and practice (II): Efficiency theories, narrative theories, and implications for reform. National Bureau of Economic Research Working Paper Series , 7119, 1999, pp.1-38.

[21] C.I. Estes and C. Phillpson, The globalization of capital, the welfare state, and old age policy. International Journal of Health Sciences ,2002, 32(2): 279-297.

[22] UN (United Nations), The Millennium Development Goals Report, 2008. Available: http://www.un.org.

[23] O.E. Eminue, Public policy analysis and decision-making. Lagos: Concept Publication, 2005.

[24] J. Miller, Families, poverty, work and care: A review of literature on parents and low income. Report No. 55, Heads CDS, 2001.

[25] G.N. Hembe, Post graduate studies in urban development and administration. Department of Political Science, Benue State University, Makurdi, Nigeria, 2002.

[26] P. Asiodu, (2000, April 5). Obasanjo's economic policies II. National Concord, 21(4251), p.35.

[27] C. Townsend, 1979, World poverty indicators. Available: https://www.google.com.

[28] M.I. Obadan, Poverty in Nigeria: Characteristics, alleviation strategies and programmes. National Centre for Economic Management and Administration (NCEMA) Policy Analysis Series, 2(2), 1996, pp, 23-46.

[29] H.H. Mersuer, Poverty in the affluent society. New York: Harper and Row, 1966.

[30] World Bank, World development report: Building institutions and markets. London: Oxford University Press and World Bank, 2002.

[31] A.A. Anyebe, An evaluation of implementation of poverty eradication programme (NAPEP) in Benue State, Nigeria. University of Benin Journal of Administration and Development (UBJAD) 2015, 1(1): $1-10$.

[32] UNDP (United Nations Development Programme), 2016, An assessment of the status of human security and human development in Nigeria. National Human Development Report. Available: www.ng.undp.org.

[33] Opejobi, S. (2016, September 5). Poverty ranking in Nigeria. Available: https://www.google.com.

[34] Radio Nigeria (2017, November, 30). 7am Network News.

[35] S. Awoyinfa, I. Chiedozie, and F. Asu (Reporters) (2019, December, 3 ). Reform now to stop further slide into extreme poverty - World Bank. The Punch Online Available: www.thepunch.ng.
[36] O. Igbuzor, Millennium Development Goals (MDGs) and poverty eradication in Nigeria. In: J. Ibrahim and O. Igbuzor (eds.), Can Nigeria meet the MDGs in 2015? Abuja: Centre for Democracy and Development, 2008.

[37] NBS (National Bureau of Statistics), 2010, Poverty rate in Nigeria. Available: https://www.nbsngr.com.

[38] BBC (British Broadcasting Corporation) Poverty rate in Nigeria, 2012. Available: www.bbc.com.newsworld-Africa-170.

[39] NBS (National Bureau of Statistics), 2020, Poverty and inequality in Nigeria 2019: $40 \%$ of total populationis classified as poor. Available: http://www.nigerianstat.gov.ng

[40] M.I. Obadan, Poverty reduction in Nigeria: The way forward. Central Bank of Nigeria (CBN) Economic and Financial Review, 39(4), 2009, pp. 31-49.

[41] Premium Times, Press Release (June 22, 2021). Buhari inaugurates committee on poverty reduction, establishes private equity fund. Available: www.premiumtimesng.com.

[42] A.A. Anyebe, Readings in development administration. Zaria: Shereef Salam Press, 2001.

[43] A. Heywood, Politics (3rd ed). New York: Palgrave Macmillan, 2007.

[44] Radio Nigeria (2017, November 2). 7am Network News.

[45] C. Gillion, Social security pension: Development and reform. International Labour OrganizationPaperSeries,2002.

[46] A. Walker and L. Foster, The political economy of ageing and later life. Cheltenham: Edward Elgar Publishing Inc., 2014.

[47] I.S. Omotola and J.M. Patrick, 2009 State responses to the Niger Delta question: The OMPADEC and NDDC compared. In: K.K. Aaron and D. George (eds.), Placebo as medicine: The poverty of development intervention and conflict resolution strategies in the Niger Delta Region of Nigeria. Port Harcourt: Kemuela Publications, 2009, pp. 116-140.

\section{About the Authors}

Cletus Iortyer Yissa holds BA (Hons.) and MSc. degrees in Public Administration from Ahmadu Bello University (ABU), Zaria and Benue State University, Makurdi, Nigeria. $\mathrm{He}$ is currently a lecturer in the Department of Public Administration, Akanu Ibiam Federal Polytechnic, Unwana, Ebonyi State, Nigeria. His research interests include collaborative public management and governance, gerontology care and welfare, and research methods. He has published articles in reputable national journals. 